\title{
THE DEVELOPMENT OF AUDITING ARENA AND CORPORATE GOVERNANCE LANDSCAPE IN MALAYSIA: AN INITIATIVE TO COMBAT FRAUD AND CORRUPTIONS
}

\author{
Nur Adura Ahmad Noruddin*, I.K. Norziaton \\ Faculty of Accountancy, Universiti Teknologi Mara Puncak Alam
}

\begin{abstract}
This research provides two phases of discussions on the evolution in auditing arena and corporate governance (CG) landscape in Malaysia. Phase 1: Pre-Malaysian Code of Corporate Governance (MCCG) (1957-2000) and Phase 2: Post-Malaysian Code of Corporate Governance (2001-2015). MCCG was designed to increase oversight and regulation of the accounting profession and to strengthen $C G$ practices and increase transparency of financial audits. The emergence of audit failures has focused the world's attention on accounting standards and the role of auditors. The cause of corporate collapse was basically due to lack of professionalism in auditing coupled with scandals on fraud and corruptions. Moreover, the quantum of fraud has increased over the past years in Malaysia and has become more sophisticated. Due to this, the Government has put all the efforts to ensure that audit and CG practices are able to comply with stringent and rigorous standards imposed by the statutory bodies as to enhance audit quality and CG practices in line with international benchmarks. Thus, this paper attempts to analyze the evolution of auditing and CG practices as initiatives taken by the Government of Malaysia in order to combat fraud and corruptions.
\end{abstract}

Keywords: Auditing, Auditors, Corporate Governance, Fraud, Corruptions

\section{INTRODUCTION}

This paper provides knowledge on the development of auditing arena and CG landscape as part of the important initiatives taken by Malaysian Government in combating fraud and corruptions. In accordance with a report by KPMG Malaysia Fraud, Bribery and Corruption Survey 2013, the quantum of fraud has increased over the past three years and has become more sophisticated. Due to this reason, the Government of Malaysia has put all the effort to ensure that the audit and CG practices are able to comply with the stringent and rigorous standards imposed by the statutory bodies as to enhance audit quality and CG practices in line with the international benchmarks. Hence, this paper provides an overall view on the evolution of auditing and CG practices as initiatives taken by the Government in order to curb and combat fraud and corruptions.

To better understand the auditing evolution and CG practices, a study was conducted by Azham et al. (2006) which examine various episodes in the Malaysian auditing saga. The duration of their study covering the period of the first 40 years post-independence in 1957 until 1997. They divided the analysis into three episodes denoting three different timeframes with reference to the dynamic changes in its political and socio-economic environment. However, this paper on

*Corresponding author's email: nurad185@salam.uitm.edu.my 
the other hand, will add on to the literature by extending the timeframe starting from 1957 to 2015. It will focus on the establishment of accounting and auditing statutory bodies and any other significant changes or amendments to the regulations through these years as initiatives taken by the Government in combating frauds and corruptions in Malaysia. This paper is organized into two phases, Phase 1: Pre-Malaysian Code of Corporate Governance (MCCG) (1957-2000) and Phase 2: Post-Malaysian Code of Corporate Governance (2001-2015). Each phase will describe the important events in the development of the auditing profession and CG practices in Malaysia. Besides that, this analysis will also enable one to understand, analyse and even interpret the initiatives taken by the Government in curbing fraud and corruptions.

\section{Objectives of the paper}

1. To provide evidences on auditing arena and CG landscape that have changed over the years to meet the needs and expectation of the society and audit profession.

2. To examine the auditing arena and CG landscape experiences in order to assess their significance and to draw reasonable lessons in combating fraud and corruptions.

\section{METHODOLOGY}

This paper is produced based on extensive reviews of related literatures including government reports and policy documents, academic papers and other publications. Sources of readings related to scandals and corporate collapses due to wrongdoings of board of directors, the unresolved ethics and independence of auditors and issues pertaining to fraud and corruptions were also referred to.

\section{The Development of Auditing Arena and CG Landscape in Malaysia}

The activities of the auditing profession in recent years are considered to be tremendously eventful. There have been many occasions where external auditors have failed in performing their duties to exercise independence and objectivity when reporting the results of their audit findings. In addition, issues of governance in corporations have become central to the public policy agenda. This has been reinforced by the shocking corporate scandals exhibited by renowned conglomerates such as Enron in 2001 and WorldCom in 2002 in the US. Thus, the combination of auditing and CG practices which has contributed to the uniqueness of the corporate environment in Malaysia will be discussed below.

\section{Phase 1: Pre-Malaysian Code on Corporate Governance (MCCG) (1957-2000)}

In order to impede the assessment of auditing arena and the emergence of CG in Malaysia, this review will start off with the establishment of the accounting and auditing statutory bodies and regulations, focusing on the post-independence development from 1957 to 1987, as shown in Figure 1 below.

*Corresponding author's email: nurad185@salam.uitm.edu.my 


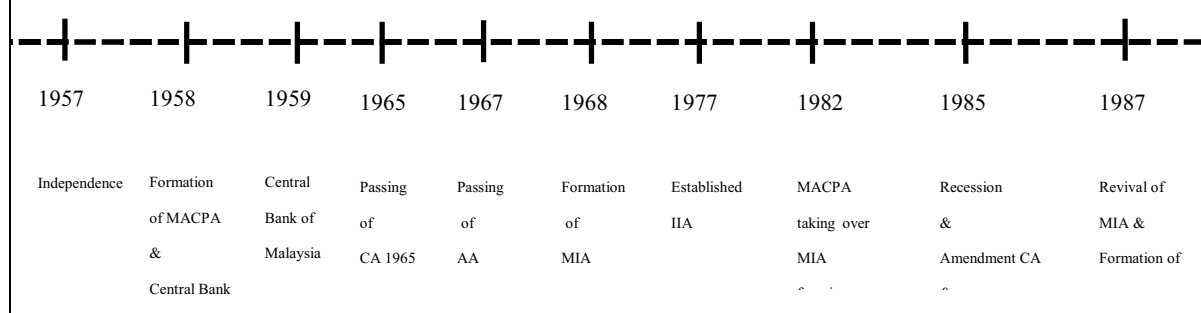

The Development of Malaysian Auditing Arena and CG Landscape from 1957 until 1987

Figure 1 Source: 1957 to 1968, 1985 \& 1987 taken from Azham et al., (2006) \& 1977 \& 1982 from current study

The Malaysian Association of Certified Public Accountants (MACPA) was established in 1958 with the main idea is to promote the status and development of accounting profession in Malaysia. On 23 October 1958, The Central Bank of Malaya Ordinance 1958 (CBO) (Central Bank of Malaya until the formation of Malaysia in 1963) was enacted while the Central Bank of Malaysia was established on 24 January 1959. At the same time, the Banking Ordinance, 1958, which provided for the licensing and regulation of the business of banking in the Federation of Malaya also came into force. Later in 1965, the Companies Act was established which sets out the rules and regulation on accounts and audit that need to be complied with by all companies in Malaysia. The Act specifically spells out the guidelines need to be addressed by auditors in terms of being independent and powers to perform such duties.

In 1967 the Government has approved the Accountants Act 1967 and the establishment of Malaysian Institute of Accountants (MIA) in 1968. It regulates the practice and promotes the interest of the accounting profession. At the same time, MIA's function is also to set on the qualification of members and to register qualified accountants under its membership. However, the statutory body was remained dormant for two decades due to the fact that it limits its role to only registering accountants. Failing to execute its function successfully, in 1982 MACPA has taken over the responsibility.

The Institute of Internal Auditors Malaysia (IIA) was set up in 1977. The main function of IIA is to assist management in ensuring that proper internal control systems are in place and the operation of the company are carried out efficiently, economically and effectively. The world economy was experiencing recessions in 1985 and following the recession, a substantial revision of the Companies Act 1965 was commenced which incorporates best accounting standards and practices, encouraging higher level of disclosures and accountability to minority shareholders including foreigners. The amendments of the Companies Act 1965 have given the auditors further responsibility towards financial statement audit. They are required to perform complete checking of transactions and to prepare a true and fair view of audited accounts. 


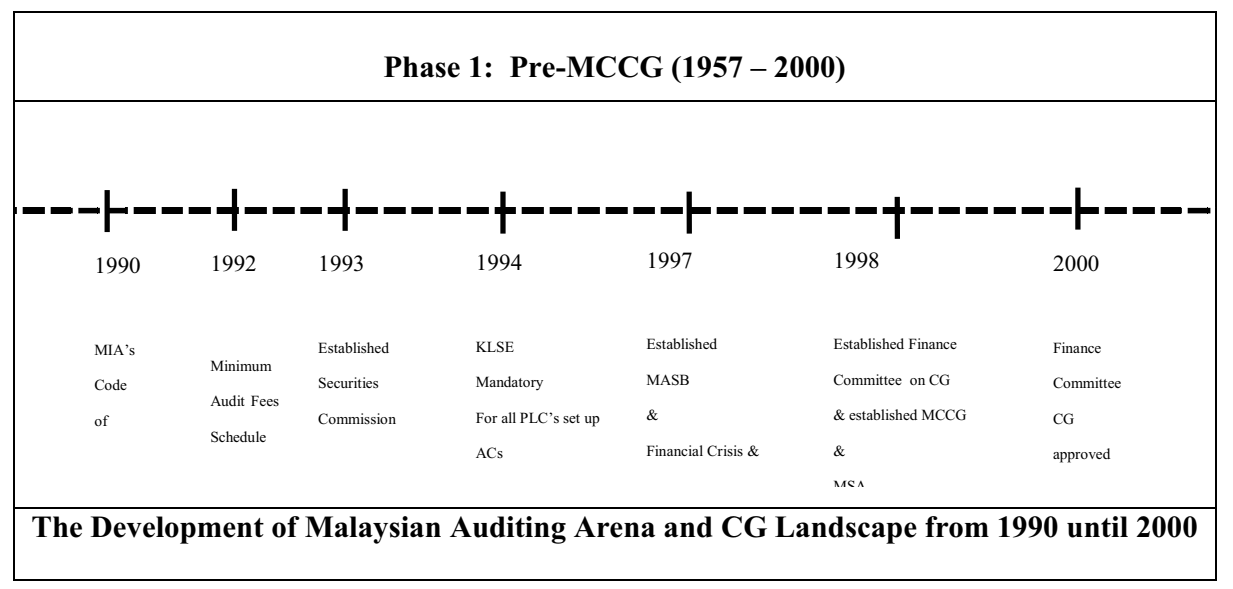

Figure 2 Source: 1990, 1992 \& 1997 taken from Azham et al., (2006) \& the remaining years are from current study

Figure 2 of the paper still draws attention to the Pre-MCCG (2000) which covers a timeframe from 1990 to 2000, as shown above. In this particular period, the functions of external auditors are to ensure the truthfulness and trustworthiness of the financial statements of their clients. Auditors are expected to enhance the credibility of the financial statements and also to provide value added services such as reporting on irregularities, identifying business risk and advising management on the internal control environment (Boynton \& Johnson, 2005). This period begins in 1990 on MIA Code of Ethics. It clearly states the primary duty of an external auditor is to prevent, detect and correcting fraud and at the same time to evaluate and report the results if they manage to recognise fraud and error that may materially affect the financial statements.

MIA under the Accountants Act 1967 was entrusted to promote and regulate the accounting profession. In doing so, the institute has proposed a schedule for determining audit fees in 1992. The intention was to harmonize the fee setting basis and to minimize disparity in fees schedule (Akauntan Nasional, 1993). The schedule was developed in response to numerous requests by members in view of maintaining high costs on accountants' staff and offices. They are also in the opinion that the scale has become essential to the auditing profession. The purpose of having a standard scale of fees for audit services are to prevent undercutting and thus protecting the auditing industry as well. As stated by the MIA's Public Practice Committee Chairmans 'in the past, there was no guideline whatsoever to say how much a firm should charge' (Akauntan Nasional, 1993). However, the audit fee schedule was only approved by MIA council to be effective beginning of April, 1993 but the schedule was ended up to be as guidelines for audit practitioners in 1994 (Akauntan Nasional, 1994). The issue of charging low audit fees is still an issue until now. Even though the MIA has provided guidelines for the audit pricing but it has not been properly adopted by most of the audit firms due to lack of enforcement by the regulatory authority (Lee et al., 2009). As a consequence, the auditors perceived that audit pricing in Malaysia are considered to be at the lower side in comparison with other countries in the region which are at a similar stage of development (Lee et al., 2009). 
The Securities Commission (SC) was established in 1993, a regulatory body for the capital market. Its main function is to regulate all matters pertaining to securities and futures market and to ensure enforcements of securities and futures laws (Khoo, 2003). SC identifies and builds up front line regulators for instance the Kuala Lumpur Stock Exchange (KLSE, now Bursa Malaysia) and self-regulatory organizations such as professional bodies which give emphasis on the auditor's responsibilities in financial statement reporting. In 1991, the MIA, in conjunction with the Malaysian Institute of Certified Public Accountants (MICPA) and the Malaysian Institute of Internal Auditors, was proposing that an audit committee to be made mandatory for companies seeking listing at the KLSE. However, later in 1994 the KLSE listing requirements has made it mandatory that every company to form an Audit Committee comprising of a majority of directors that were independent of the company's management.

In 1997, Malaysia became the first Asia country to set up its own accounting standard setting body, the Malaysian Accounting Standards Board (MASB) (Akauntan Nasional, 2003). It carries a function of an independent standard setting body for establishing financial accounting and reporting standards in Malaysia. It was set up as to bring harmonization between national and international accounting standards. MASB has been developing standards with reference to the accounting standards issued by the International Accounting Standards Board (IASB). With regards to the convergence with International Financial Reporting Standards (IFRSs) in Malaysia, MASB has taken all necessary steps in promoting high quality and transparent financial reporting.

In making further and better provision for the prevention of corruption and for matters necessary thereto and connected therewith, the Anti-Corruption Act 1997 which formerly known as Act 575 was formed. The Anti-Corruption Agency was then established with the function to investigate and prosecute corruptions in the public and private sectors (The Commissioner of Law Revision, Malaysia, 2006). Affords have been put forward by the Government on the development of CG in Malaysia. The initiative started off with the establishment of Finance Committee on Corporate Governance in 1998 which consists of both government and industry. The recognition on CG was evidenced by the released of the MCCG by the Committee in March 2000. The codes focus on four main areas that are board of directors, director's remuneration, shareholders and accountability and auditing. In March 1998, the High Level Finance Committee on Corporate Governance established the Malaysian Institute of Corporate Governance (MICG). It is a non-profit public company limited by guarantee, with founding members consisting of the Federation of Public Listed Companies (FPLC), MIA, MICPA, Malaysian Institute of Chartered Secretaries and Administrators (MAICSA), and Malaysian Institute of Directors (MID). MICG's mandate was to raise the awareness and practice of CG in Malaysia.

Prior to 1998, Malaysia had no standardised set of approved auditing standards. In this regard, MIA has been adopting most of these standards from the International Federation of Accountants (IFAC) as the main criteria to assess the appropriateness of accounting treatment. Later in July 1998, MIA had approved standards on auditing known as Malaysian Standards on Auditing (MSA) which is strictly adhere to the International Auditing Standards (IASs). These guidelines and recommendations on auditing together with the adopted IFAC standards have form the Generally Accepted Auditing Principles (GAAP) in Malaysia. Thus, professional accountants in public practice are expected to comply with these standards in the performance of their audits under all reporting framework. Transparency International Malaysia (TI-M) was also established in 1998. As an independent, non-governmental and nonpartisan organisation committed to the fight against corruption, the mission is to eradicate corruptions and promote transparency, integrity and accountability throughout society. 
Through these establishments, it is evidenced that the Government has continuously putting efforts in combating fraud and corruptions in Malaysia.

Minority Shareholder Watchdog Group (MSWG) was another Government's initiative set up in 2000 as a body that looks after the interest of minority shareholders. Act as a non-profit organization, it is intended to protect minority shareholders' right, increase awareness among them of their responsibilities, and ensure they understand their role in an organization. This was due to the fact that minority shareholders were left in the lurch when companies collapses and were often the last to know. Therefore, this shareholder activism is said to positively affecting companies in enhancing the shareholder's value (The Star, July 8, 2009).

In short, the auditing developments that took place after independence basically are more concerned with the establishment of accounting and auditing professional bodies which are mainly MIA and MACPA. Throughout these years there are also some changes made on the accounting and auditing regulations which to certain extend have some implications on the role of external auditor in carrying out their audit engagement. During this period, it can be observed that the audit function is not only focusing on preventing and detecting fraud and errors but also assessing the truth and fairness of the companies' financial statements. Later the practice of auditing in Malaysia highlighted the financial reporting framework which includes the standards, legal responsibilities, codes of conduct and reporting requirements that guide the financial statement auditor's work. It also draws the attention to the professional, regulatory and standard setting bodies that directly impact the auditing profession. This auditing arena and CG landscape are an important introduction to the complex and ever-changing environment involving the elements of fraud and corruptions in which financial statement auditing is performed.

\section{Phase 2: Post-Malaysian Code of Corporate Governance (2001-2015)}

Sarbanes Oxley Act (SOX) was released in July 2002, the most comprehensive corporate reform and financial market protection as a reaction to the string of financial scandals in the U.S. It was designed with the intention to increase oversight and regulation of the accounting profession after the collapse of Enron and its auditor Arthur Andersen (Cosgrove \& Niederjohn, 2008). The Act aimed to strengthen the CG and increase transparency of financial audits in the U.S. However, it does not only affecting the CG issues in the U.S. but also other Asian countries including Malaysia.

As shown in Figure 3 below, the Post-MCCG covers from years 2001 until 2015. With regards to this timeframe, the role of auditors is expected to converge. They are expected to carry out duties up to the expectations of the public, to maintain high standards of professionalism and to uphold a good reputation in auditing profession (Accountants Today, 2008). 


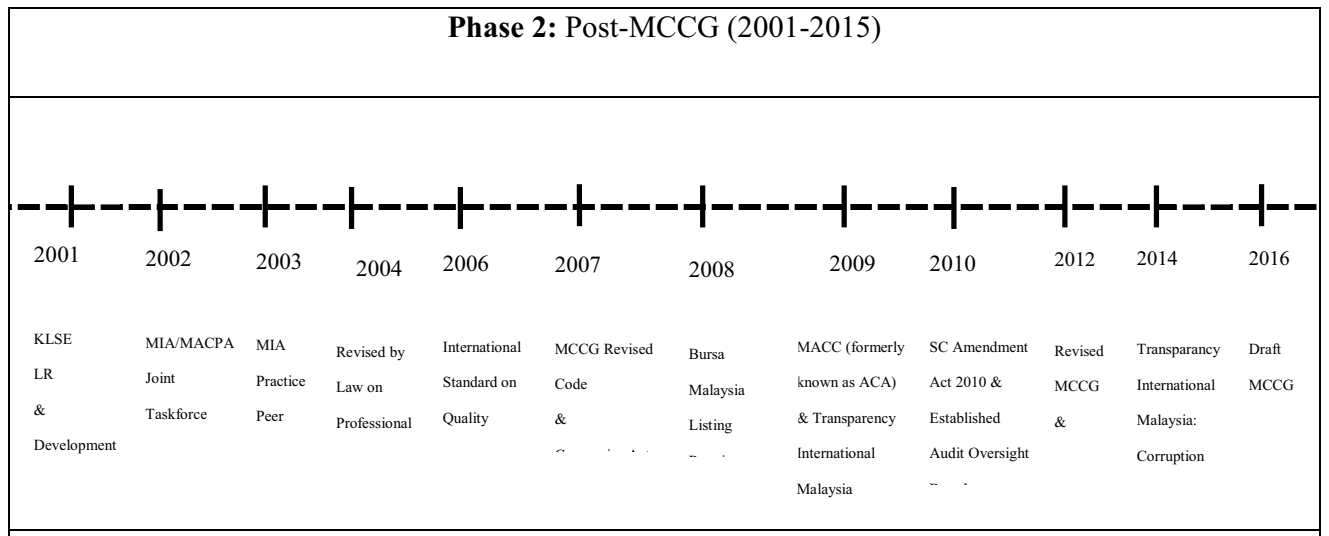

The Development of Malaysian Auditing Arena and CG Landscape from 2001 until 2015

Figure 3 Source: All sources are from current study

The KLSE has revamped its Listing Requirements in year 2001, subsequent to the MCCG's suggestions on the Corporate Governance Best Practices in 2000. The main requirement amongst other requires that all listed companies to disclose a 'CG Statement' in their annual report and its level of compliance with the code. Other than that, companies are also required to disclose a 'Statement on Internal Control' which clearly states the internal control system of the company and to explain the responsibility of the Board in preparing the annual audited accounts. The new Listing requirements also emphasised on the role and composition of audit committee in the company.

In May 2002, the two accounting professional bodies agreed to establish an MIA/MACPA Joint Taskforce on Auditor Independence (MIA 2002). Given that auditor independence and competency is directly unobservable to the Malaysian investing public at the moment, a revised By-Law on Professional Independence was issued in 2004 responding to the SOX issued in the U.S. The main objective of the By-Law is to make it compulsory for all external auditors to be independent of clients for whom audit engagements are conducted (MIA 2004). Whereby, the auditors are expected to separate its non-audit functions and other advisory services since the role of auditors has always been seen as highly associated with such services to audit clients. The MIA's practice review which was introduced in 2003 applies to all member firms that conduct audits. Practice review refers to the evaluation of the work performed by the auditors and of these firms' internal quality controls (Business News, 2014). The work of a practising accountant is to be reviewed by another qualified member of the profession. In other words, the MIA Practice Review Committee is acting as a monitoring mechanism to gauge members' compliance with professional standards and to oversee the implementation of this programme. In areas where the standards are found to be lacking, the committee might give suggestions and recommendations for improvement.

With regards to audit quality, International Standards on Quality Control (ISQC) 1 was introduced in July 2006 by MIA. According to Omar et. al (2006), the MIA has urged all audit firms to comply with ISQC 1 . Additionally, by implementing ISQC 1 it would enhance the audit quality and preparing those firms to face competitive marketplace. Once again in year

*Corresponding author's email: nurad185@salam.uitm.edu.my 
2007, the Securities Commission (SC) released a revised MCCG as to further improve the Malaysia's CG framework. The Revised Code of best practices 2007 intend to intensify the roles and responsibilities of board of directors and audit committee and to ensure that they perform their responsibilities effectively (MCCG, 2007). The revised Code also requires that all public listed companies to carry out their own internal audit functions. The MCCG best practices however became mandatory under the new Bursa Malaysia Listing Requirements (BMLR) in 2008. The revised Listing Requirements was designed to increase oversight and regulation with major provisions on the role of board and audit committees within organization and, the competency of the internal audit function. Following the revision, several important amendments to the Companies Act 1965 have been made. The new provisions are in response to the role and duties of auditors as to promote better auditing practice. The amendment of the Companies Act includes new provision which relates to duty to inform upon ceasing to hold office as auditor (section 172A) and detection of fraud by auditors (section 174 and 174A).

Apart from the above amendments, the whistle blowing law in the Companies Act 1965 has been removed and embodied in the Capital Market and Services Act (CMSA) 2007 (Accountants Today, 2009). The whistle blowing provisions under Section 320 of the CMSA imposes mandatory duty upon auditors of listed corporations to report breaches of the securities law and stock exchange rules to the authority. At the same time, CMSA also contain provisions that prevent victimization of whistle blower. Therefore, the role of statutory auditors is highly controversial with more responsibilities and duties that need to be complied with in ensuring that the company's accounts are trustworthy and reliable.

Another initiative taken by the Government in combating fraud and corruption is through the formation of Malaysian Anti-Corruption Commission (MACC) Act. The Act is formerly known as Anti-Corruption Agency Act 1997 came into effect on 1 January 2009. This has led to the official establishment of MACC as an independent, transparent and professional body effectively and efficiently manage Malaysia's anti-corruption efforts. Through the formation of five panels of independent body with the function to closely and constantly monitor MACC, in order to ensure its integrity and to protect citizens' rights. The 'Check and Balance Mechanisms' consists of the Anti-Corruption Advisory Board, the Special Committee on Corruption, the Complaints Committee, the Operations Review Panel, and the Corruption Consultation and Prevention Panel. The recent passage of the Securities Commission Amendment Act 2010 in Parliament has made the Audit Oversight Board (AOB) is now a reality. $\mathrm{AOB}$ in Malaysia was established as to create a new governance structure that will enhance quality of audit services by auditors (Ismail and Mustapha 2015). This is seen as a direct response to the serious irregularities in financial reporting in Malaysia. Therefore, the $\mathrm{AOB}$ is said to provide an independent oversight and regulation to external auditors of public listed companies in Malaysia. The board also has the power to reprimand auditors that had done wrong including issuing penalty and deregistering them from the audit practice (Ismail and Mustapha 2015). The Transparency International Malaysian (TI-M) was also introduced in 2009. It is an independent, non-governmental and non-partisan organization committed to the fight against corruption. The Government has commission in the Prime Minister Department, and a consultant, Ethos and Company to engage TI-M in a series of discussions on ways to curb corruptions. By these establishments as mentioned above, it can be seen the Government has taken great initiatives in curbing and combating fraud and corruptions in Malaysia.

On 6 May 2010, the Parliament of Malaysia has passed the Whistleblower Protection Act, which came into force on December 2010. Whistleblowers will be protected under the Act for 
the report lodged relating to disclosure of improper conducts to any seven of the top government agencies including MACC, the Royal Malaysian Police, Royal Malaysian Customs, Road Transport Department of Malaysia, Immigration Department of Malaysia, Securities Commission of Malaysia and CCM. The Act empowers enforcement agencies to investigate into complaints of detrimental action and allows the court to order damages, compensation, injunction any order remedies against the party who makes the detrimental action. Year 2012 marks another milestone in CG landscape when the MCCG 2012 superseded the MCCG 2007. With the revision of the MCCG in 2012, the BMLR was further revised in November 2012. Although the requirement on audit committee characteristics and internal audit function attributes were not raised, there are now additional requirements on CG such as the establishment of nomination committee (Norziaton 2013).

In 2014, the Transparency International Malaysia (TI-M) which was established in 1998 has launched the results of the Corruption Perception Index (CPI) as well as the Malaysian Corruption Barometer (MCB). Datuk Akhbar Satar, the President of TI-M mentioned that the score and ranking of Malaysia between 2011- 2012 have improved (The Edge Financial Daily, 2014). The CPI ranks countries based on the perceived level of corruptions in the public sector. The score of 0 is for "highly corrupt" and the score of 100 is for "very clean". Those scores can be considered as a positive feedback from experts and laymen on the Government's initiatives in combating fraud and corruptions in those years. The annual report of TI-M 2009 also reported after the launch of 2009 Corruption Perception Index (CPI), Malaysia showed a drastic drop of 5.1 to 4.5 and the country ranking from 47 to 56 . On the other hand, the 2014 MCB results reported a decrease in the perceived levels of corruption in Malaysia compared to 2013, along with a decline in the belief that corruption in the public sector in Malaysia is a problem. The perception that Malaysia's government is run by a few big interests looking out for themselves also rated better in 2014 compared to 2013. The reported results by TI-M explained that the initiatives taken by the Government to curb and combat frauds and corruption have contributed to positive outcomes in controlling the level of fraud and corruption in Malaysia.

To end the evolution of auditing arena and CG landscape in Malaysia, this study reveals that in 2016, the SC has issued a Proposed Draft of MCCG. As a key document in Malaysia's corporate governance framework the Code has contributed significantly in improving the corporate governance standards of Malaysian listed companies. As mentioned in the earlier section, the Code has been reviewed and revised twice in 2007 and again in 2012. The effort to consistently revise the Code is seen as part of the serious initiatives undertaken by the Government in combating frauds and corruptions in Malaysia.

\section{CONCLUSIONS}

This paper relates to the development of auditing arena and CG landscape in Malaysia which covers a timeframe starting from post-independence in 1957 until 2015. Several key developments have occurred as to guide the auditors in carrying out audit practice more diligently and to enhance the integrity of financial statement audit. Over the years, stringent rules and regulations were imposed by the Government which needs to be conforming by the statutory auditors especially after the release of MCCG 2000. Hence, extra audit procedures are to be undertaken in performing the audit assignment. Based on the discussions on the two phases above, this paper has demonstrated auditing arena and CG landscape in Malaysia that has evolved over the years starting from an establishment of professional bodies and regulations until the divergence of the auditing profession. Hence, the changes that took place 
over these periods clearly state that considerable resource have been channeled to the evolution of the auditing arena and CG landscape in Malaysia. The Government's continuous initiative in curbing and combating fraud and corruptions can be seem as great efforts in making sure of fraud and corruptions in Malaysia are under good control. According to the Auditor General, Tan Sri Ambrin Buang the number of fraud cases, forgery and corruption in corporate Malaysia are under control as the government introduces new measures and policies to mitigate the risks (Business Times, 26 July, 2010). It is hoped that Malaysia Government will consistently able to manage fraud and corruptions through the revision of existing procedures and several other new mechanisms which may be introduced in the future.

\section{REFERENCES:}

Accountants Today, (2008). Enhancing Audit Quality: Impact of the Audit Oversight Board.

Accountants Today, (2009). Auditors and the Whistleblowing Law from http://www.mia.org.my/at/at/2009/04/04.pdf

Akauntan Nasional, (1993). MIA Sets Standard Audit Fees

Akauntan Nasional, (April 1994). Submission by the Council of the Malaysian Institute of Accountants on Guidelines for Minimum Audit Fees - An Overview

Akauntan Nasional (March 2003). Striving For Quality Financial Reporting

Azham A., Roszaini H., Mohammad H. (2006). Episodes in the Malaysian Auditing Saga, Managerial Auditing Journal, Volume 21, Issue 7, 684-701

Boynton W.C., Johnson R.N. (2005). Modern Auditing: Assurance Services and Integrity of Financial Reporting, $8^{\text {th }}$ Edition, Wiley.

Business News (29 March 2014). Auditing The Auditors

Business Times, (26 July, 2010). Corporate Fraud, Graft 'Under Control'.

Cosgrove, S. B., and Niederjohn, M. S. (2008). The effects of the Sarbanes-Oxley Act of 2002 on audit fees. Journal of Business Strategies, 25(1), 31.

http://transparency.org.my/

http://www.mia.org.my/handbook/guide/masa/AI600.htm

Ismail H., Mustapha M. (2015). Auditing the Auditors: The Audit Oversight Board and Regulating Audit Quality in Malaysia, Journal of Modern Accounting and Auditing, March 2015, Vol. 11, No. 3, 138-142

Khoo B. Y. (2003). Review of Corporate Governance in Asia: Corporate Governance in Malaysia, http://adbi.org/file/2003.11.10.corporate.governance.malaysia.pdf

*Corresponding author's email: nurad185@salam.uitm.edu.my 
KPMG Malaysia (2003). Fraud, Bribery and Corruption Survey

Lee, T., Azham, A., Gloeck, J. (2009). The Audit Expectation Gap in Malaysia: An Investigation Into Its Causes and Remedies. Southern African Journal of Accountability and Auditing Research, 9.

MASB (Malaysian Accounting Standards Board). Retrieved on 21 March 2010 from http://www.masb.org.my.

MCCG (Malaysian Code of Corporate Governance) (2007). Malaysian Law Journal Sdn. Bhd., Malaysia.

MIA (2002) By Laws (on Professional Ethics, Conducts and Practices) of the Malaysian Institute of Accountants from http://www.mia.org.my

MIA (2004) By Laws (on Professional Ethics, Conducts and Practices) of the Malaysian Institute of Accountants from http://www.mia.org.my

Norziaton I.K. (2013). Internal Governance Mechanisms and Audit Fees: The Moderating Role of Political Connection and Regulatory Oversight, Thesis Submitted for the Degree of Doctor of Philosophy, Universiti Malaya

Omar N., Mohd Sanusi Z., Yaakob N.A.,Mohamed S. (2013). Audit Quality Assessment on Audit Firm: Compliance and Challenges, The $5^{\text {th }}$ International Conference on Financial Criminology

Sarbanes Oxley Act (2002) from http://www.sec.gov.

SC (Securities Commission Malaysia). Retrieved on 5 November, 2011 from http://www.sc.com.my/.

The Commissioner of Law Revision, Malaysia, 2006

The Edge Financial Daily (December 4, 2014). Malaysia Moves Up 3 Spots in Global Graft Index

The Star, (July 8, 2009). Shareholder Activism Can Enhance Shareholders Value.

Transparency International Malaysia Annual Report 2009 from http://transparency.org.my/

*Corresponding author's email: nurad185@salam.uitm.edu.my 